Acta Crystallographica Section C

Crystal Structure

Communications

ISSN 0108-2701

Editor: George Ferguson

\title{
A supramolecular zigzag chain of organometallic dipoles mediated by $\mathrm{PF}_{6}$ - anions
}

M. Teresa Duarte, M. Fátima M. Piedade, M. Paula Robalo, António P. S. Teixeira and M. Helena Garcia

Copyright $\odot$ International Union of Crystallography

Author(s) of this paper may load this reprint on their own web site provided that this cover page is retained. Republication of this article or its storage in electronic databases or the like is not permitted without prior permission in writing from the IUCr. 
Acta Crystallographica Section C

\section{Crystal Structure}

Communications

ISSN 0108-2701

\section{A supramolecular zigzag chain of organometallic dipoles mediated by $\mathrm{PF}_{6}{ }^{=}$anions}

\author{
M. Teresa Duarte, ${ }^{a *}$ M. Fátima M. Piedade, ${ }^{b}$ M. Paula \\ Robalo, ${ }^{c}$ António P. S. Teixeira ${ }^{\mathrm{d}}$ and M. Helena Garciab
}

${ }^{a}$ Centro de Química Estrutural, Instituto Superior Técnico, Avenida Rovisco Pais, 1049-001 Lisboa, Portugal, 'bepartamento de Química e Bioquímica, Faculdade de Ciências da Universidade de Lisboa, Campo Grande, 1749-016 Lisboa, Portugal, 'Departamento de Engenharia Química, Instituto Superior de Engenharia de Lisboa, Rua Conselheiro Emídio Navarro, 1, 1949-014 Lisboa, Portugal, and dDepartamento de Química, Universidade de Évora, Colégio Luís António Verney, Rua Romão Ramalho, 59, 7000-671 Évora, Portugal

Correspondence e-mail: teresa.duarte@ist.utl.pt

Received 10 May 2005

Accepted 4 July 2005

Online 23 July 2005

The title compound, ( $\eta^{5}$-cyclopentadienyl)(4-nitrobenzonitrile- $\kappa N)($ trimethylphosphine $-\kappa P)($ triphenylphosphite- $\kappa P)$ iron(II) hexafluorophosphate, $\left[\mathrm{Fe}\left(\mathrm{C}_{5} \mathrm{H}_{5}\right)\left(\mathrm{C}_{7} \mathrm{H}_{4} \mathrm{~N}_{2} \mathrm{O}_{2}\right)\left(\mathrm{C}_{18^{-}}\right.\right.$ $\left.\left.\mathrm{H}_{15} \mathrm{O}_{3} \mathrm{P}\right)\left(\mathrm{C}_{3} \mathrm{H}_{9} \mathrm{P}\right)\right] \mathrm{PF}_{6}$, has been characterized by spectroscopic and $\mathrm{X}$-ray diffraction in order to evaluate the tuning of the electron density at the metal centre and the extension of the $\pi$ delocalization on the molecule due to the presence of phosphite and phosphine co-ligands. The compound crystallizes in the centrosymmetric space group $P 2_{1} / c$, which destroys the possibility of exhibiting any quadratic non-linear optical properties. The packing shows a supramolecular zigzag chain of antiparallel cations connected via the $\mathrm{PF}_{6}{ }^{-}$anions through $\mathrm{C}-\mathrm{H} \cdots \mathrm{F}^{\delta-}$ interactions, with $\mathrm{H} \cdots \mathrm{F}$ distances ranging from 2.39 to $2.67 \AA$. Each zigzag chain is composed of isomeric organometallic fragments containing either $R$ or $S$ molecules. These chains are connected through weak intermolecular $\mathrm{C}-$ $\mathrm{H}$. C C interactions, forming a two-dimensional plane parallel to (101).

\section{Comment}

The design of new monocyclopentadienyl metal derivatives for application in materials science has engrossed scientists in recent years. Our interest in these compounds stems from their use as building blocks in a three-dimensional network, which would allow us to explore new variables for the engineering and development of new solids with potential nonlinear optical (NLO) applications. It is well known that molecular polarization is responsible for high values of molecular hyperpolarizability, so tailoring the building blocks by modifying either the metal centre or the ligand environment will change and possibly enhance the molecular polarization (Whittall et al., 1998; Nalwa, 1991; Goovaerts et al., 2001). With the aim of modifying the electronic richness of the metallic centre, we have recently studied a family of iron(II) complexes $\left[\mathrm{Fe}(\mathrm{Cp})(L)\left(L^{\prime}\right)(p-\mathrm{NCR})\right] \mathrm{BF}_{4} \quad\left[\mathrm{Cp}\right.$ is $\eta^{5}$-cyclopentadienyl; $L$ and $L^{\prime}$ are $\mathrm{CO}, \mathrm{P}(\mathrm{OPh})_{3}$ or $\mathrm{PPh}_{3} ; R$ is $\mathrm{C}_{6} \mathrm{H}_{4} \mathrm{NMe}_{2}, \mathrm{C}_{6} \mathrm{H}_{4} \mathrm{NO}_{2}$, $(E)-\mathrm{CH}=\mathrm{CHC}_{6} \mathrm{H}_{4} \mathrm{NMe}_{2}$ or $(E)-\mathrm{CH}=\mathrm{CHC}_{6} \mathrm{H}_{4} \mathrm{NO}_{2}$ ], where the organometallic fragment has been systematically enriched or depleted by changing the ligands $L$ and $L^{\prime}$ or substituting the $\eta^{5}$-cyclopentadienyl ligand with $\eta^{5}$-indenyl (Garcia, Robalo, Teixeira et al., 2001). Within these studies, we have synthesized and characterized the title novel complex, $\left[\mathrm{Fe}(\mathrm{Cp})\left(\mathrm{PMe}_{3}\right)\left\{\mathrm{P}(\mathrm{OPh})_{3}\right\}\left(4-\mathrm{NCC}_{6} \mathrm{H}_{4} \mathrm{NO}_{2}\right)\right] \mathrm{PF}_{6}$, (I), and present its structural analysis here.

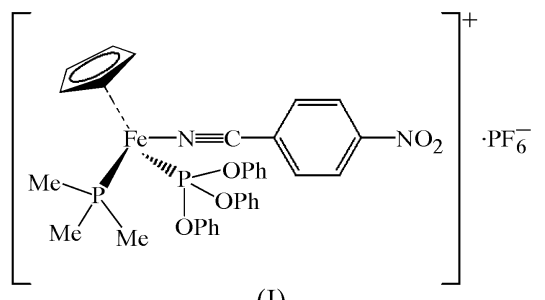

(I)

Complex (I) was synthesized by treatment of the precursor $\left[\mathrm{Fe}(\mathrm{Cp})\left\{\mathrm{P}(\mathrm{OPh})_{3}\right\}\left(\mathrm{PMe}_{3}\right) \mathrm{I}\right]$ with $\mathrm{TlPF}_{6}$ and a slight excess of 4-nitrobenzonitrile in dichloromethane at room temperature. After work-up and recrystallization with dichloromethanediethyl ether, complex (I) was obtained as dark-red crystals, which were fairly stable towards oxidation in air and moisture in both the solid state and solution. The formulation is supported by analytical data and IR and ${ }^{1} \mathrm{H},{ }^{13} \mathrm{C}$ and ${ }^{31} \mathrm{P}$ NMR spectra. In the IR spectrum, the typical $v(\mathrm{CN})$ band at $2220 \mathrm{~cm}^{-1}$ showed a negative shift of $12 \mathrm{~cm}^{-1}$ compared with the uncoordinated nitrile, as observed previously for other analogous $\mathrm{Fe}^{\mathrm{II}}$ compounds (Garcia, Robalo, Dias et al., 2001). In the NMR spectrum, we observed a doublet signal at 8.05 p.p.m. for the aromatic ortho $\mathrm{H}$ atoms of the nitrile ligand, which is slightly shielded when compared with the corresponding signal for the uncoordinated nitrile (8.13 p.p.m. in the same solvent). These spectroscopic data are consistent with a metal-nitrile interaction, described by a nitrile $\sigma$-type

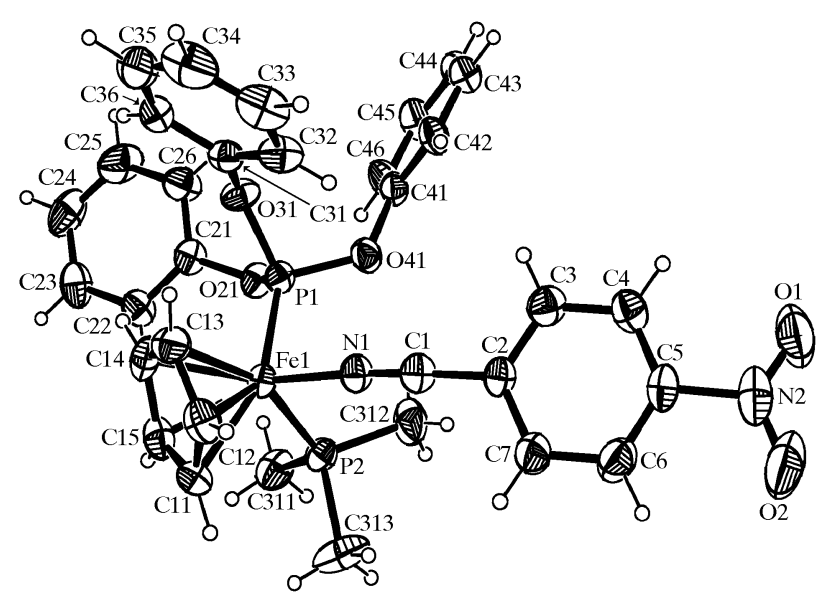

Figure 1

A view of the complex cation in (I), showing $30 \%$ probability displacement ellipsoids and the atomic labelling scheme. 


\section{metal-organic compounds}

coordination with a small $\pi$ back-donation contribution, owing to $\pi$-bonding between the metal $d$ orbitals and the $\pi^{*}$ orbital of the $\mathrm{CN}$ group. The complex shows an intense broad visible absorption band at $\lambda_{\max }=435 \mathrm{~nm}$ in chloroform. This absorption could be attributed to a $d-\pi^{*}$ metal-to-ligand charge-transfer (MLCT) transition from the Fe centre to the nitrile ligand. Such low-energy MLCT bands are typically associated with large molecular quadratic NLO responses (Garcia, Robalo, Dias et al., 2001; Garcia et al., 2002).

In the solid state, complex (I) crystallizes in the monoclinic centrosymmetric space group $P 2_{1} / c$, thus destroying our hopes of obtaining dipole supramolecular alignment. The molecular structure of the cation is presented in Fig. 1. The coordination geometry can be described as a pseudo-octahedral threelegged piano stool on the assumption that the cyclopentadienyl group takes up three coordination sites. This geometry, similar to that of other compounds of the same family (Garcia, Robalo, Teixeira et al., 2001), is confirmed by the angles around the metal centre, which are all close to $90^{\circ}$ (Table 1 ), as well as by the remaining $X-\mathrm{Fe}-\mathrm{Cp}$ (centroid) angles [P1$\mathrm{Fe} 1-\mathrm{Cp}($ centroid $)=124.62(6)^{\circ}, \mathrm{P} 2-\mathrm{Fe} 1-\mathrm{Cp}($ centroid $)=$ $122.67(6)^{\circ}$ and $\mathrm{N} 1-\mathrm{Fe} 1-\mathrm{Cp}($ centroid $\left.)=123.4(1)^{\circ}\right]$. As expected, all angles involving the $\mathrm{Cp}$ centroid are considerably larger than those involving the phosphite, phosphine and nitrile ligands.

In the molecule of (I), we observe the well known contraction of the $\mathrm{Fe}-\mathrm{P}$ bond when using a phosphite ligand instead of phosphine. Thus, the observed value of $2.1206(14) \AA$, which is shorter than that of the trimethylphosphine ligand [2.2332(15) $\AA$ ], can be attributed to the presence of the oxygen as the $\alpha$ atom of the pendent groups on the triphenylphosphite. This value agrees with the values observed for $\mathrm{Fe}$ (phosphine) and $\mathrm{Fe}$ (phosphite) derivatives in the Cambridge Structural Database (CSD, Version 5.25; Allen, 2002), presented in Table 3, where $\mathrm{Fe}-\mathrm{N}$ and $\mathrm{N} \equiv \mathrm{C}$ distances are also included for comparison.

The $\mathrm{Fe}-\mathrm{N}$ distance $[1.871(4) \AA]$ in $(\mathrm{I})$ is somewhat shorter than that found in $\left[\mathrm{Fe}(\mathrm{Cp})(\mathrm{CO})\left\{\mathrm{P}(\mathrm{OPh})_{3}\right\}\left(4-\mathrm{NCC}_{6} \mathrm{H}_{4} \mathrm{NO}_{2}\right)\right]-$ $\mathrm{BF}_{4}$ [1.878 (10) $\AA$; Garcia, Robalo, Teixeira et al., 2001], while it is very similar to that observed in $[\mathrm{Fe}(\mathrm{Cp})(\mathrm{dppe})(4-$ $\mathrm{NCC}_{6} \mathrm{H}_{4} \mathrm{NO}_{2}$ ) $] \mathrm{PF}_{6} \quad[1.874(11) \AA$; dppe is (diphenylphosphino)ethane; Garcia, Robalo, Dias et al., 2001]. The $\mathrm{N} \equiv \mathrm{C}$

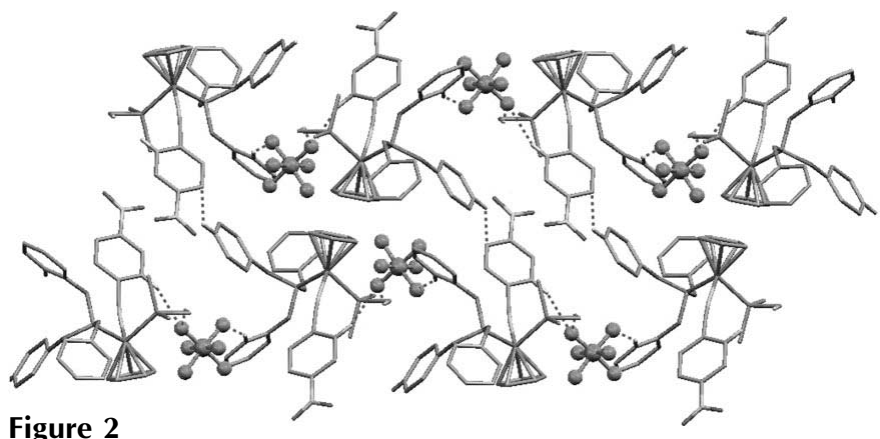

A view of the two-dimensional layer of zigzag chains formed by different optical isomers of the complex cation. $\mathrm{H}$ atoms not involved in hydrogen bonding have been omitted. Broken lines indicate $\mathrm{C}-\mathrm{H} \cdots \mathrm{F}$ and $\mathrm{C}-$ $\mathrm{H} \cdots \mathrm{C}(\pi)$ interactions. bond [1.147 (6) $\AA$ ], being somewhat longer than the corresponding bonds found in the complexes listed in Table 3, approaches the structural features of the bond in the free imine [1.155 (15) ^; Higashi \& Osaki, 1997]. These values, altogether with the bond angles $\mathrm{Fe} 1-\mathrm{N} 1 \equiv \mathrm{C} 1$ and $\mathrm{N} 1 \equiv \mathrm{C} 1-$ $\mathrm{C} 2$ [175.4 (4) and $173.7(5)^{\circ}$, respectively], show that, in the solid state, the nitrile group departs somewhat from the expected linear geometry, and there is no evidence of any appreciable $\pi$ back-donation contribution. These results confirm the spectroscopic data found for (I), since only a small $\pi$ back-donation effect was noticed. According to this behaviour, which can be correlated with the donor ability of the metal centre, we can identify the $\left[\mathrm{Fe}(\mathrm{Cp})\left(\mathrm{PMe}_{3}\right)\left\{\mathrm{P}(\mathrm{OPh})_{3}\right\}\right]^{+}$ fragment as a weak $\pi$-donor towards the nitrile ligand when compared with other fragments (Table 3 ).

In recent publications, the importance of intermolecular interactions involving halogens, in particular $\mathrm{F}$ atoms, as a possible tool in crystal engineering has been studied in great detail (Chopra et al., 2005). The three-dimensional packing of (I) shows a supramolecular organometallic zigzag chain of aligned cations (of the same conformational isomer) in an updown configuration, obtained via a network of $\mathrm{C}-\mathrm{H} \cdots \mathrm{F}^{\delta-}$ interactions (Table 2) involving the $\mathrm{F}$ atoms of the anions and $\mathrm{H}$ atoms of the nitrile $\left[\mathrm{H} 7 \cdots \mathrm{F} 6^{\mathrm{i}}\right.$; symmetry code: (i) $1-x,-y$, $1-z]$, phosphine $\left(\mathrm{H} 33 A \cdots \mathrm{F} 6^{\mathrm{i}}\right)$ and phosphite $\left[\mathrm{H} 42 \cdots \mathrm{F}^{\mathrm{ii}}\right.$; symmetry code: (ii) $x, \frac{1}{2}-y, z-\frac{1}{2}$ ] (Fig. 2), generating in this way a one-dimensional chain along the $b$ axis. We have taken into account the criteria used by Reichenbacher et al. (2005), where $\mathrm{H}$ - . F distances up to $2.9 \AA$ can be considered as weak intermolecular interactions. These interactions organize the complex cations into pairs through the spherical anion, in such a way that their dipole moments and second-order polarizabilities cancel. A weaker interaction of the type $\mathrm{C}-$ $\mathrm{H} \cdots \mathrm{C}(\pi)$, between a $\mathrm{C}$ atom of the benzene ring attached to the nitrile and a phenyl $\mathrm{H}$ atom of the phosphite ligand [C34$\mathrm{H} 34 \cdots \mathrm{C} 4{ }^{\mathrm{iii}}$; symmetry code: (iii) $\left.x, \frac{1}{2}-y, z+\frac{1}{2}\right]$, gives rise to the formation of a two-dimensional aggregation of chains of different optical isomers of the complex cation parallel to the (101) plane.

\section{Experimental}

$\mathrm{TlPF}_{6} \quad(0.40 \mathrm{mmol})$ was added to a solution of $[\mathrm{Fe}(\mathrm{Cp})-$ $\left.\left\{\mathrm{P}(\mathrm{OPh})_{3}\right\}\left(\mathrm{PMe}_{3}\right) \mathrm{I}\right](0.40 \mathrm{mmol})$ and 4-nitrobenzonitrile $(0.72 \mathrm{mmol})$ in dichloromethane $(40 \mathrm{ml})$ at room temperature. The mixture was stirred at room temperature for $22 \mathrm{~h}$. A colour change was observed from dark brown to red, with simultaneous precipitation of thallium iodide. The red solution was filtered, evaporated under vacuum to dryness, and washed several times with diethyl ether and $n$-hexane to remove the excess of nitrile. The dark-red residue was further purified by vapour diffusion of diethyl ether into a concentrated dichloromethane solution, affording dark-red crystals of (I) (yield $47 \%$; m.p. 435-436 K). Analysis calculated for $\mathrm{C}_{33} \mathrm{H}_{33} \mathrm{~F}_{6} \mathrm{FeN}_{2} \mathrm{O}_{5} \mathrm{P}_{3}$ : C 49.49, H 4.16, N 3.50\%; found: C, 49.44, H 4.12, N 3.31\%. IR (KBr, $\left.\mathrm{cm}^{-1}\right): v(\mathrm{~N} \equiv \mathrm{C}) 2221, v\left(\mathrm{NO}_{2}\right) 1526$ and $1345 ;{ }^{1} \mathrm{H}$ NMR $(300 \mathrm{MHz}$, $\left.\mathrm{CD}_{3} \mathrm{COCD}_{3}\right): \delta 1.85\left(d, 9 \mathrm{H}, J=9.0 \mathrm{~Hz}, \mathrm{PMe}_{3}\right), 4.64\left(s, 5 \mathrm{H}, \eta^{5}-\mathrm{C}_{5} \mathrm{H}_{5}\right)$, $7.23\left[\mathrm{~m}, 3 \mathrm{H}, \mathrm{P}(\mathrm{OPh})_{3}: \mathrm{H}\right.$-para $], 7.34-7.42\left[m, 12 \mathrm{H}, \mathrm{P}(\mathrm{OPh})_{3}: \mathrm{H}\right.$-ortho and $\mathrm{H}-m e t a], 8.05(d, 2 \mathrm{H}, J=9.0 \mathrm{~Hz}, \mathrm{H} 2, \mathrm{H} 6), 8.41(d, 2 \mathrm{H}, J=9.0 \mathrm{~Hz}$, $\mathrm{H} 3, \mathrm{H} 5) ;{ }^{13} \mathrm{C}\left\{{ }^{1} \mathrm{H}\right\}$ NMR $\left(75 \mathrm{MHz}, \mathrm{CD}_{3} \mathrm{COCD}_{3}\right): \delta 18.85\left(d, J_{\mathrm{CP}}=\right.$ 
$\left.-29.8 \mathrm{~Hz}, \mathrm{PMe}_{3}\right), 81.69\left(\eta^{5}-\mathrm{C}_{5} \mathrm{H}_{5}\right), 118.29(\mathrm{C} 1), 121.70\left[d, J_{\mathrm{CP}}=\right.$ $6.8 \mathrm{~Hz}, \mathrm{P}(\mathrm{OPh})_{3}:$ C-ortho $], 125.28$ (C3, C5), $126.17\left[\mathrm{P}(\mathrm{OPh})_{3}: \mathrm{C}-\right.$ para $]$, $131.00\left[\mathrm{P}(\mathrm{OPh})_{3}: \mathrm{C}-\right.$ meta $], 132.81$ (NC), 135.00 (C2, C6), 152.44 [P(OPh $)_{3}$ :C-ipso], $152.59(\mathrm{C} 4) ;{ }^{31} \mathrm{P}\left\{{ }^{1} \mathrm{H}\right\}$ NMR $\left(75 \mathrm{MHz}, \mathrm{CD}_{3} \mathrm{COCD}_{3}\right)$ : $\delta-144.05\left(h, J_{\mathrm{PF}}=704.4 \mathrm{~Hz}, \mathrm{PF}_{6}\right), 27.93\left(d, J_{\mathrm{PP}}=100.3 \mathrm{~Hz}, \mathrm{PMe}_{3}\right)$, $167.93\left[d, J_{\mathrm{PP}}=100.3 \mathrm{~Hz}, \mathrm{P}(\mathrm{OPh})_{3}\right]$. During the NMR experiment, no sign of nitrile ligand dissociation was found in deutero-acetone.

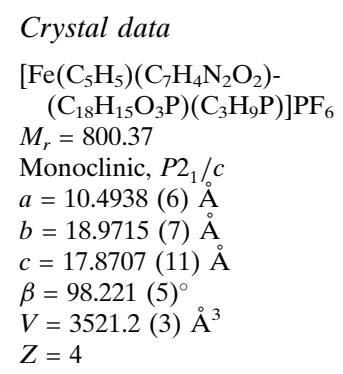

\author{
$D_{x}=1.510 \mathrm{Mg} \mathrm{m}^{-3}$ \\ $\mathrm{Cu} K \alpha$ radiation \\ Cell parameters from 25 \\ reflections \\ $\theta=16-21^{\circ}$ \\ $\mu=5.39 \mathrm{~mm}^{-1}$ \\ $T=293(2) \mathrm{K}$ \\ Plate, red \\ $0.3 \times 0.14 \times 0.1 \mathrm{~mm}$
}

\title{
Data collection
}

Enraf-Nonius TurboCAD-4 diffractometer

$\omega / 2 \theta$ scans

Absorption correction: part of the refinement model $(\Delta F)$

(Parkin et al., 1995)

$T_{\min }=0.276, T_{\max }=0.583$

6598 measured reflections

6598 independent reflections

\section{Refinement}

Refinement on $F^{2}$

$R\left[F^{2}>2 \sigma\left(F^{2}\right)\right]=0.064$

$w R\left(F^{2}\right)=0.150$

$S=1.08$

6598 reflections

451 parameters

$\mathrm{H}$-atom parameters constrained

$$
\begin{aligned}
& 3926 \text { reflections with } I>2 \sigma(I) \\
& \theta_{\max }=69.8^{\circ} \\
& h=-12 \rightarrow 12 \\
& k=0 \rightarrow 23 \\
& l=0 \rightarrow 21 \\
& 3 \text { standard reflections } \\
& \quad \text { every } 400 \text { reflections } \\
& \quad \text { intensity decay: none }
\end{aligned}
$$

\begin{tabular}{|c|c|c|c|c|}
\hline Compound & $\mathrm{Fe}-\mathrm{P}_{\mathrm{PPh}}$ & $\mathrm{Fe}-\mathrm{P}_{\mathrm{POPh}}$ & $\mathrm{Fe}-\mathrm{N}$ & $\mathrm{N} \equiv \mathrm{C}$ \\
\hline$\left[\mathrm{Fe}(\mathrm{Cp})(\mathrm{dppe})\left(\mathrm{NCCH}_{3}\right)\right] \mathrm{BPh}_{4}{ }^{a}$ & $\begin{array}{l}2.205 \\
2.194\end{array}$ & & 1.881 & 1.137 \\
\hline$\left[\mathrm{Fe}(\mathrm{Cp})(\mathrm{dppm})\left(\mathrm{NCCH}_{3}\right)\right] \mathrm{PF}_{6}{ }^{b}$ & $\begin{array}{l}2.194 \\
2.196 \\
2.207\end{array}$ & & 1.892 & 1.135 \\
\hline$\left[\mathrm{Fe}\left(\right.\right.$ acetyl-Cp) $($ dppe $\left.)\left(\mathrm{NCCH}_{3}\right)\right] \mathrm{PF}_{6}{ }^{c}$ & $\begin{array}{l}2.207 \\
2.232\end{array}$ & & 1.895 & 1.126 \\
\hline$\left[\mathrm{Fe}(\mathrm{Cp} *)(\mathrm{dppe})\left(\mathrm{NCCH}_{3}\right)\right] \mathrm{PF}_{6}{ }^{d}$ & $\begin{array}{l}2.218 \\
2.237\end{array}$ & & 1.905 & 1.133 \\
\hline$\left[\mathrm{Fe}(\mathrm{Cp})\left\{\mathrm{P}(\mathrm{OPh})_{3}\right\}_{2}\left(\mathrm{NCCH}_{3}\right)\right] \mathrm{PF}_{6}{ }^{e}$ & & $\begin{array}{l}2.143 \\
2.165\end{array}$ & 1.918 & 1.132 \\
\hline$\left[\mathrm{Fe}(\mathrm{Cp})\left\{\mathrm{P}(\mathrm{OMe})_{3}\right\}_{2}\left(\mathrm{NCCH}_{3}\right)\right] \mathrm{PF}_{6}{ }^{f}$ & & $\begin{array}{l}2.175 \\
2.182\end{array}$ & 1.924 & 1.094 \\
\hline $\begin{array}{l}{\left[\mathrm{Fe}(\mathrm{Cp})(\mathrm{dppe})\left(\mathrm{NCPhNO}_{2}\right)\right]-} \\
\mathrm{PF}_{6},(\mathrm{II})\end{array}$ & $\begin{array}{l}2.209(3) \\
2.210(4)\end{array}$ & & 1.874 (11) & $1.129(1$ \\
\hline $\begin{array}{l}{\left[\mathrm{Fe}(\mathrm{Cp})(\mathrm{CO})\left\{\mathrm{P}(\mathrm{OPh})_{3}\right\}(\mathrm{NCPh}-\right.} \\
\left.\left.\mathrm{NO}_{2}\right)\right] \mathrm{BF}_{4},(\mathrm{III})\end{array}$ & & $2.159(3)$ & $1.878(10)$ & $1.139(1$ \\
\hline $\begin{array}{l}{\left[\mathrm{Fe}(\mathrm{Ind})(\mathrm{CO})\left\{\mathrm{P}(\mathrm{OPh})_{3}\right\}(\mathrm{NCPh}-\right.} \\
\left.\left.\mathrm{NO}_{2}\right)\right] \mathrm{BF}_{4}{ }^{g}\end{array}$ & & $2.139(3)$ & $1.900(8)$ & $1.155(12$ \\
\hline $\begin{array}{l}{\left[\mathrm{Fe}(\mathrm{Cp})(\mathrm{dppp})\left(\mathrm{NCPhNO}_{2}\right)\right]-} \\
\mathrm{PF}_{6},(\mathrm{IV})\end{array}$ & $\begin{array}{l}2.211(3) \\
2.219(3)\end{array}$ & & $1.902(9)$ & $1.141(15)$ \\
\hline $\begin{array}{l}{\left[\mathrm{Fe}(\mathrm{Cp})\left(\mathrm{PMe}_{3}\right)\left\{\mathrm{P}(\mathrm{OPh})_{3}\right\}-\right.} \\
\left.\quad\left(\mathrm{NCPhNO}_{2}\right)\right] \mathrm{PF}_{6},(\mathrm{I}) \\
p-\mathrm{NCPhNO}_{2},(\mathrm{~V})\end{array}$ & $2.233(2)$ & $2.121(1)$ & $1.871(4)$ & $1.147(6)$ \\
\hline
\end{tabular}

$$
\begin{gathered}
w=1 /\left[\sigma^{2}\left(F_{\mathrm{o}}{ }^{2}\right)+(0.0514 P)^{2}\right. \\
+1.6778 P] \\
\text { where } P=\left(F_{\mathrm{o}}{ }^{2}+2 F_{\mathrm{c}}^{2}\right) / 3 \\
(\Delta / \sigma)_{\max }=0.013 \\
\Delta \rho_{\max }=0.41 \mathrm{e}^{-3} \\
\Delta \rho_{\min }=-0.27 \mathrm{e}^{-3}
\end{gathered}
$$

Table 3

Comparative geometrical parameters $(\AA)$ for selected complexes.

Ddpe is diphenylphosphphinoethane, dppm is bis(diphenylphosphino)methane and geometrical parameters taken from the Cambridge Structural Database are indicated without their s.u. values.

References: (I) this work; (II) Garcia, Robalo, Dias et al. (2001); (III) Garcia, Robalo, Teixeira et al. (2001); (IV) Wenseleers et al. (2003); (V) Higashi \& Osaki (1977). CSD refcodes: (a) PEACFE (Riley et al., 1978); (b) VEBSIE (Ruiz et al., 1989); (c) KEJPOE (Ruiz, Gonzalez et al., 1990); (d) KICNIT (Ruiz, Astruc et al., 1990); (e) XATDUR (Katayama et al., 2000); ( $f$ ) JIPYAI (Schumann et al., 1991); (g) QUSPOJ (Garcia, Robalo, Teixeira et al., 2001).

Methyl $\mathrm{H}$ atoms were positioned geometrically, with $\mathrm{C}-\mathrm{H}=$ $0.96 \AA$, and constrained. The $\mathrm{H}$ atoms of the $\mathrm{Ph}$ and $\mathrm{Cp}$ rings were also positioned geometrically, with $\mathrm{C}-\mathrm{H}=0.93 \AA$. For all $\mathrm{H}$ atoms, $U_{\text {iso }}(\mathrm{H})=1.2 U_{\text {eq }}(\mathrm{C})$.

Data collection: CAD-4 EXPRESS (Enraf-Nonius, 1994); cell refinement: XCAD4 (Harms \& Wocadlo, 1995); data reduction: $X C A D 4$; program(s) used to solve structure: SIR99 (Altomare et al., 1999); program(s) used to refine structure: SHELXL97 (Sheldrick, 1997); molecular graphics: ORTEP-3 (Farrugia, 1997) and MERCURY (Bruno et al., 2002); software used to prepare material for publication: WinGX (Farrugia, 1999), PLATON (Spek, 2003) and enCIFer (Allen et al., 2004).

Supplementary data for this paper are available from the IUCr electronic archives (Reference: OB1231). Services for accessing these data are described at the back of the journal.

\section{References}

Allen, F. H. (2002). Acta Cryst. B58, 380-388.

Allen, F. H., Johnson, O., Shields, G. P., Smith, B. R. \& Towler, M. (2004). J. Appl. Cryst. 37, 335-338.

Altomare, A., Burla, M. C., Camalli, M., Cascarano, G., Giacovazzo, C., Guagliardi, A., Moliterni, A. G. G., Polidori, G. \& Spagna, R. (1999). J. Appl. Cryst. 32, 115-119.

Bruno, I. J., Cole, J. C., Edgington, P. R., Kessler, M., Macrae, C. F., McCabe, P., Pearson, J. \& Taylor, R. (2002). Acta Cryst. B58, 389-397.

Chopra, D. \& Guru Row, T. N. (2005). J. Mol. Struct. 733, 133-141.

Enraf-Nonius (1994). CAD-4 EXPRESS. Version 5.1/1.2. Enraf-Nonius, Delft, The Netherlands.

Farrugia, L. J. (1997). J. Appl. Cryst. 30, 565.

Farrugia, L. J. (1999). J. Appl. Cryst. 32, 837-838. 


\section{metal-organic compounds}

Garcia, M. H., Robalo, M. P., Dias, A. R., Duarte, M. T., Wenseleers, W., Aerts, G., Goovaerts, E., Cifuentes, M. P., Hurst, S., Humphrey, M. G., Samoc, M. \& Luther-Davies, B. (2002). Organometallics, 21, 2107-2118.

Garcia, M. H., Robalo, M. P., Dias, A. R., Piedade, M. F. M., Galvão, A., Wenseleers, W. \& Goovaerts, E. (2001). J. Organomet. Chem. 619, 252-264. Garcia, M. H., Robalo, M. P., Teixeira, A. P. S., Dias, A. R., Piedade, M. F. M. \& Duarte, M. T. (2001). J. Organomet. Chem. 632, 145-156.

Goovaerts, E., Wenseleers, W. E., Garcia, M. H. \& Cross, G. H. (2001). Handbook of Advanced Electronic and Photonic Materials, Vol. 9, edited by H. S. Nalwa, pp. 127-191. San Diego: Academic Press.

Harms, K. \& Wocadlo, S. (1995). XCAD4. University of Marburg, Germany. Higashi, T. \& Osaki, K. (1977). Acta Cryst. B33, 2337-2339.

Katayama, T., Onitsuka, K. \& Takahashi, S. (2000). J. Organomet. Chem. 610, 31-37.

Nalwa, H. S. (1991). Appl. Organomet. Chem. 5, 349-377 .

Parkin, S., Moezzi, B. \& Hope, H. (1995). J. Appl. Cryst. 28, 53-56.

Reichenbacher, K., Suss, H. I. \& Hulliger, J. (2005). Chem. Soc. Rev. 34, 22-30.
Riley, P. E., Capshew, C. E., Pettit, R. \& Davis, R. E. (1978). Inorg. Chem. 17, 408-414.

Ruiz, J., Astruc, D., Bideau, J. P. \& Cotrait, M. (1990). Acta Cryst. C46, 23672369.

Ruiz, J., Garland, M.-T., Roman, E. \& Astruc, D. (1989). J. Organomet. Chem. 377, 309-326.

Ruiz, J., Gonzalez, M. A., Roman, E. \& Garland, M. T. (1990). J. Chem. Soc. Dalton Trans. pp. 21-27.

Schumann, H., Eguren, L. \& Ziller, J. W. (1991). J. Organomet. Chem. 408, 361-380.

Sheldrick, G. M. (1997). SHELXL97. University of Göttingen, Germany.

Spek, A. L. (2003). J. Appl. Cryst. 36, 7-13.

Wenseleers, W., Goovaerts, E., Hepp, P., Garcia, M. H., Robalo, M. P., Dias, A. R., Piedade, M. F. M. \& Duarte, M. T. (2003). Chem. Phys. Lett. 367, 390397.

Whittall, I. R., McDonagh, A. M., Humphrey, M. G. \& Samoc, M. (1998). Adv. Organomet. Chem. 42, 291-362. 